\title{
UTILITY OF PROSTATE SPECIFIC ANTIGEN IN THE DIAGNOSIS OF VARIOUS PROSTATIC LESIONS
}

\author{
Shashidhar M. $R^{1}$, Shariff M. $H^{2}$
}

${ }^{1}$ Assistant Professor, Department of Pathology, Yenepoya Medical College, Mangaluru.

${ }^{2}$ Associate Professor, Department of Pathology, Yenepoya Medical College, Mangaluru.

ABSTRACT
BACKGROUND
Carcinoma of the prostate is the most common internal malignancy among men in the United States and $10^{\text {th }}$ common malignancy in
India. It accounts for 33\% of all malignant tumours in men and responsible for $9 \%$ of all deaths due to cancer. Prostate specific
antigen (PSA), a glycoprotein serine protease, was first identified by Wang et al in 1979. Prostate specific antigen (PSA) is a substance
produced exclusively by certain cells within the male prostate gland. PSA is the most useful tumour marker in diagnosis and first line
test in screening.
The aims of this study were-

1. To evaluate the utility of PSA assay as a method of investigation in diagnosis of prostatic lesions.

2. To correlate morphological types with serum PSA levels.

\section{MATERIALS AND METHODS}

The present study was undertaken in a tertiary care hospital of Yenepoya Medical College, Mangaluru and 184 cases were studied over a period of 2 years from 2015 to 2016. In all investigated individuals, the pre-treatment serum PSA levels were measured by chemiluminescence immunoassay technique using Vitros 5600. Serum PSA level $<4 \mathrm{ng} / \mathrm{mL}$ was considered normal. Histopathological analysis of obtained material was done on standard Haematoxylin-Eosin (H\&E) preparations.

\section{RESULTS}

Out of 181 cases, 164 cases showed benign prostatic hyperplasia. Among benign prostatic hyperplasia of 164 cases, 100 cases had serum PSA of 0-4 ng/mL, 39 cases with $4-10 \mathrm{ng} / \mathrm{mL}$ and 25 cases had $>10 \mathrm{ng} / \mathrm{mL}$. We reported 17 cases of adenocarcinoma of 181 cases, in with majority (15 cases) of the patients had serum PSA of $>10 \mathrm{ng} / \mathrm{mL}$, and two cases showed serum PSA of $4-10 \mathrm{ng} / \mathrm{mL}$. In our study, positive predictive value (PPV) was found to be $37.5 \%$ and negative predictive value (NPV) was $98.58 \%$ for cut-off PSA level of $10 \mathrm{ng} / \mathrm{mL}$. Similarly, sensitivity and specificity of our test for PSA level $10 \mathrm{ng} / \mathrm{mL}$ was $88.23 \%$ and $84.75 \%$ respectively.

\section{CONCLUSION}

Study confirms the high prevalence of adenocarcinoma of prostate in high serum PSA level of the patient but not all prostate cancers are associated with an elevated serum PSA level. Hence, there is a need of estimation and interpretation of different PSA forms like free PSA levels, prostatic density, PSA velocity, etc. to improve the sensitivity and specificity of PSA.

\section{KEYWORDS}

PSA, Benign, Adenocarcinoma, Histopathology, Prostate.

HOW TO CITE THIS ARTICLE: Shashidhar MR, Shariff MH. Utility of prostate specific antigen in the diagnosis of various prostatic lesions. J. Evolution Med. Dent. Sci. 2016;5(89):6598-6601, DOI: 10.14260/jemds/2016/1492

\section{BACKGROUND}

The prostate is a pear-shaped glandular organ that weighs up to $20 \mathrm{~g}$ in the normal adult male and that depends for its differentiation and subsequent growth on androgenic hormones synthesised in the testis, acting through a poorly understood mesenchymal-epithelial interaction. ${ }^{1}$ The prostate is a retroperitoneal organ encircling the neck of the bladder and urethra, and is devoid of a distinct capsule. In the adult, prostatic parenchyma can be divided into four biologically and anatomically distinct zones or regions: The peripheral, central, and transitional zones, and the region of

Financial or Other, Competing Interest: None.

Submission 19-10-2016, Peer Review 31-10-2016,

Acceptance 03-11-2016, Published 05-11-2016.

Corresponding Author:

Dr. Shashidhar M. R,

Assistant Professor,

Department of Pathology,

Yenepoya Medical College,

Deralakatte,

Mangaluru-575018.

E-mail: shash.mr@gmail.com

DOI: $10.14260 /$ jemds $/ 2016 / 1492$

\section{(c) (i) $(9)$}

the anterior fibromuscular stroma. ${ }^{2}$ The inner zone is the primary site for nodular hyperplasia (and the rare carcinomas arising from large ducts), whereas the outer zone is the site of predilection for the ordinary adenocarcinoma arising from peripheral ducts and acini. 3,4

Carcinoma of the prostate is the most common internal malignancy among men in the United States and $10^{\text {th }}$ common malignancy in India. ${ }^{5}$ India ranks 5 th in incidence and 4 th in mortality for men in Mumbai. It accounts for 33\% of all malignant tumours in men and responsible for $9 \%$ of all deaths due to cancer. ${ }^{6}$ The diagnosis requires careful history, physical examination including digital rectal examination (DRE), serum prostate specific antigen (PSA) estimation and transrectal ultrasound (TRUS) and TRUS-guided needle biopsies of the prostate.

Among these, the biopsies are considered as gold standard for the tissue diagnosis of the prostatic cancer. ${ }^{7}$ Prostate specific antigen (PSA), a glycoprotein serine protease, was first identified by Wang et al in 1979. Prostate specific antigen (PSA) is a substance produced exclusively by certain cells within the male prostate gland. Biochemically, it belongs to the protease family of kallikrein and is also known as human kallikrein 3 (hK3). ${ }^{8}$ 
PSA is the most useful tumour marker in diagnosis and first line test in screening. The increase in serum PSA depends on differentiation of tumour cells. ${ }^{1}$

The first line of screening for prostatic cancer consists of annual digital rectal examination (DRE) and estimation of serum PSA level. The upper limit of normal for PSA values is generally considered to be $4.0 \mathrm{ng} / \mathrm{mL}$; between 4 and 10 $\mathrm{ng} / \mathrm{mL}$ is considered borderline and more than $10 \mathrm{ng} / \mathrm{mL}$ is considered high. Patients with a PSA value greater than 4 $\mathrm{ng} / \mathrm{mL}$, irrespective of DRE results, generally undergo biopsy. ${ }^{9}$

\section{Aims and Objectives}

(i) To study prevalence of distribution of various prostatic lesions, in the region of Dakshina Kannada (Karnataka).

(ii) To evaluate the utility of PSA assay as a method of investigation in diagnosis of prostatic lesions.

(iii) To correlate morphological types with Serum PSA levels.

\section{MATERIALS AND METHODS}

Yenepoya Medical College, Mangaluru is one of the largest and well-known urology, nephrology, transplant and diagnostic centre in Dakshina Kannada (Karnataka)

The present study was undertaken in a tertiary care hospital of Yenepoya Medical College, Mangaluru and 184 cases were studied over a period of 2 years from 2015 to 2016.

A thorough clinical history of every patient with particular reference to age, presenting complaints of obstructive voiding such as hesitancy, poor flow, intermittent stream, dribbling, sensation of poor bladder emptying, episodes of retention and irritative symptoms like frequency, nocturia, urgency, urge incontinence and also abnormality on DRE were recorded. All patients underwent thorough general physical examination, abdominal examination including genitourinary examination.

In all investigated individuals, the pre-treatment serum PSA levels were measured by chemiluminescence immunoassay technique using Vitros 5600. Serum PSA level $<4 \mathrm{ng} / \mathrm{mL}$ was considered normal.

Histopathological analysis of obtained material was done on standard Haematoxylin-Eosin (H\&E) preparations, statistical analyses were done wherever necessary.

\section{RESULTS}

In present study, out of 181 cases, 164 cases showed benign lesions with mean age 65 years and 15 malignant lesions with mean age 70.66 years, and 2 cases of PIN (Prostatic Intraepithelial Neoplasia) with mean age of 64 years (Table 1).

\begin{tabular}{|c|c|c|}
\hline Sl. No. & $\begin{array}{c}\text { Mean Age } \\
\text { in Years }\end{array}$ & $\begin{array}{c}\text { No. of } \\
\text { Cases (\%) }\end{array}$ \\
\hline Benign Lesions & 65 & 90.60 \\
\hline Malignant Lesions & 70.66 & 8.28 \\
\hline PIN & 64 & 1.10 \\
\hline \multicolumn{2}{|c|}{$\begin{array}{c}\text { Table 1. Distribution of Patients age } \\
\text { in Various Prostatic Lesions }\end{array}$} \\
\hline
\end{tabular}

In our study, the mean serum PSA was 19.2. Out of 181 cases, 164 cases showed benign prostatic hyperplasia. Among benign prostatic hyperplasia of 164 cases, 100 cases had serum PSA of 0-4 ng/mL, 39 cases with $4-10 \mathrm{ng} / \mathrm{mL}$ and 25 cases had $>10 \mathrm{ng} / \mathrm{mL}$.
We reported 17 cases of adenocarcinoma of 181 cases, in with majority ( 15 cases) of the patients noted with serum PSA of $>10 \mathrm{ng} / \mathrm{mL}$, and two cases showed serum PSA of 4-10 $\mathrm{ng} / \mathrm{mL}$.

\begin{tabular}{|c|c|c|}
\hline PSA ng/mL & $\begin{array}{c}\text { BPH } \\
\text { (No. of Cases) }\end{array}$ & $\begin{array}{c}\text { Carcinoma } \\
\text { (No. of Cases) }\end{array}$ \\
\hline $0-4$ & 100 & 0 \\
\hline $4-10$ & 39 & 2 \\
\hline$>10$ & 25 & 15 \\
\hline TOTAL & 164 & 17 \\
\hline \multicolumn{2}{|c|}{ Table 2. Histopathology Diagnosis } \\
with Corresponding PSA level \\
\hline
\end{tabular}

Mean Serum PSA was 19.52

In our study, positive predictive value (PPV) was found to be $37.5 \%$ and negative predictive value (NPV) was $98.58 \%$ for cut-off PSA level of $10 \mathrm{ng} / \mathrm{mL}$

Similarly, sensitivity and specificity of our test for PSA level $10 \mathrm{ng} / \mathrm{mL}$ was $88.23 \%$ and $84.75 \%$ respectively.

Out of 181 cases, 164 cases (90.60\%) showed benign prostatic hyperplasia with benign tumour cells arranged in nodules consisting hyperplastic fibromuscular stroma and benign hyperplastic prostatic glands showing branching and double layer epithelium. Many of the glands showed corpora amylacea (Figure A).

17 cases $(8.28 \%)$ were reported as adenocarcinoma of prostate showing tumour cells arranged in glandular, acini, crowded, cords and scattered singly. These glands are lined by single layer of cells with no outer basal layer. The tumour cells may be clear, dark and eosinophilic cells. Clear cells have foamy cytoplasm, dark cells have homogeneous basophilic cytoplasm, and eosinophilic cells have granular cytoplasm. The cells may show varying degree of anaplasia and mild-tomoderate nuclear atypia (Figure B).

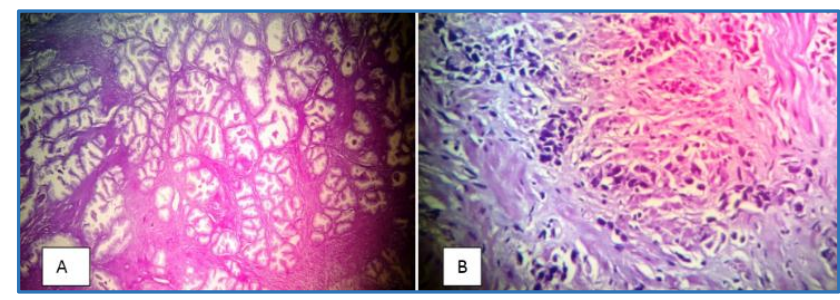

Figure 1. H \& E Sections showing Benign Prostatic Hyperplasia (A) and Adenocarcinoma of Prostate (B)

\section{DISCUSSION}

PSA is one of the most important biomarkers for diagnosing prostate cancer and helps the clinicians to decide for the biopsies. The gold standard triad for diagnosing prostate cancer comprised DRE, PSA level and transrectal ultrasonography aiding to improve the detection rate of the prostate cancer.

Patients were aged predominantly between $45-78$ Yrs. The mean age at diagnosis in this study was 58 yrs.

In patients with benign prostatic hyperplasia, $100(61 \%)$ had serum PSA of less than $4 \mathrm{ng} / \mathrm{mL}, 39$ (23.8) had serum PSA in the range of 4 to $10 \mathrm{ng} / \mathrm{mL}$ and $25(15.2 \%)$ patients had serum PSA more than $10 \mathrm{ng} / \mathrm{mL}$. 
Almost all patients (89\%) with adenocarcinoma had raised serum PSA of more than $10 \mathrm{ng} / \mathrm{mL}$, only two patients $(11.76 \%)$ were having a serum PSA of than $4-10 \mathrm{ng} / \mathrm{mL}$. This study revealed a statistically significant correlation between serum PSA and adenocarcinoma. These findings were consistent with the study conducted by Janardan et al.

\begin{tabular}{|c|c|c|c|c|c|}
\hline Lesion & $\begin{array}{c}\text { Present } \\
\text { Study }\end{array}$ & $\begin{array}{c}\text { Alpesh } \\
\text { et al7 }\end{array}$ & $\begin{array}{c}\text { Jevan } \\
\text { et al10 }\end{array}$ & $\begin{array}{c}\text { Arun } \\
\text { Chitale11 }\end{array}$ & $\begin{array}{c}\text { Janardan } \\
\text { et al7 }\end{array}$ \\
\hline BPH & $90.60 \%$ & $81.53 \%$ & $83 \%$ & $89 \%$ & $93.90 \%$ \\
\hline CAP & $8.28 \%$ & $6.87 \%$ & $17 \%$ & $11 \%$ & $6.06 \%$ \\
\hline \multicolumn{6}{|c|}{ Table 3. Comparison of Benign and Malignant } \\
Proliferative Lesions with Other Studies
\end{tabular}

In this study, the positive predictive value for increasing PSA levels was $37.5 \%$ for PSA $>10 \mathrm{ng} / \mathrm{mL}$ compared to Akther et al ${ }^{12}$ which was $24.2 \%$.

\begin{tabular}{|c|c|c|c|c|c|c|c|c|c|}
\hline PSA Range ng/mL & \multicolumn{4}{|c|}{ Benign Prostatic Hyperplasia } & \multicolumn{5}{|c|}{ Carcinoma Prostate } \\
\hline & $\begin{array}{c}\text { Present } \\
\text { Study }\end{array}$ & $\begin{array}{l}\text { Kshitij } \\
\text { et al }{ }^{13}\end{array}$ & $\begin{array}{c}\text { Eshtiaq } \\
\text { Ali }^{14}\end{array}$ & Prabhat 15 & $\begin{array}{l}\text { Kshitij } \\
\text { et al } 13\end{array}$ & Mwaaykoma16 & Sladana 17 & Prabhat 15 & $\begin{array}{c}\text { Present } \\
\text { study }\end{array}$ \\
\hline $0-4$ & $60.9 \%$ & 71.6 & - & - & 10.5 & - & 2.5 & - & - \\
\hline $4-10$ & $23.7 \%$ & 22.6 & 85 & 87.6 & 23.6 & 5.3 & 27.50 & 14.9 & 11.6 \\
\hline$>10$ & $15.2 \%$ & 3.0 & 15 & 12.4 & 63.7 & 94.7 & 70.0 & 74.2 & 88.3 \\
\hline
\end{tabular}

In our study, 39 (23.8\%) had serum PSA in the range of 4 to $10 \mathrm{ng} / \mathrm{mL}$ and $25(15.2 \%)$ patients had serum PSA more than $10 \mathrm{ng} / \mathrm{mL}$ diagnosed as benign prostatic hyperplasia. The above findings i.e. a rise in serum PSA level $\geq 4 \mathrm{ng} / \mathrm{mL}$ does not always indicate the presence of prostatic cancer because benign conditions such as hyperplasia and prostatitis can also increase the serum PSA levels. ${ }^{18,19,15}$

Similarly, only two patients $(11.76 \%)$ were diagnosed as adenocarcinoma in spite of having a serum PSA of $4-10 \mathrm{ng} / \mathrm{mL}$. This is explained by few cancers that are so poorly differentiated that the epithelial cells lose expression of a PSA encoding gene. ${ }^{20}$ Therefore, a proliferating tumour does not reveal increased serum PSA levels and this can practically lead to diagnosis of tumour at later stages and poor prognosis than tumours producing more PSA. ${ }^{15}$

\section{CONCLUSION}

Study confirms the high prevalence of adenocarcinoma of prostate in patients with high serum PSA levels, but not all prostate cancers are associated with an elevated serum PSA level. Hence, there is a need of estimation and interpretation of different PSA forms like free PSA levels, prostatic density, PSA velocity, etc. to improve the sensitivity and specificity of PSA. To conclude histopathological evaluation is confirmatory for diagnosis of prostatic lesions.

\section{REFERENCES}

1. Cunha GR. Role of mesenchymal-epithelial interactions in normal and abnormal development of the mammary gland and prostate. Cancer 1994;74(3):1030-44.

2. McNeal JE. Normal and pathologic anatomy of prostate. Urology 1981;17(Suppl 3):11-6.

3. Blennerhassett JB, Vickery AL. Carcinoma of the prostate gland. Cancer 1996;19:980-4.

4. Kirchheim D, Niles NR, Frankus E, et al. Correlative histochemical and histological studies on thirty radical prostatectomy specimens. Cancer 1966;19(11):1683-96.

5. Gurumurthy D, Maggad R, Patel S. Prostate carcinoma: correlation of histopathology with serum prostate specific antigen. International Journal of Science, Technology and Society. Special issue: latest different concepts of gynaecology. Science Journal of Clinical Medicine 2015;4(4-1):1-5.
6. Anusha AM, Ranjith S, Annamala PT. Correlation between prostate specific antigen and acid phosphatase with histopathological findings in various prostatic pathologies. SSRG International Journal of Medical Science (SSRG-IJMS) 2015:2(6):1-6.

7. Hingrajia NM, Desai $H$, Goswami $H M$, et al. Histopathological study of transrectal ultrasound guided biopsies of prostate in patients with raised serum prostate specific antigen. NHL Journal of Medical Sciences 2015;4(1):70-4.

8. Maru AM, Makwana HH, Lakum NR, et al. Study on correlation between Prostate Specific Antigen (PSA) and various prostatic pathology. Int J Med Sci Public Health 2014;3(6):735-7.

9. Jasani JH, Patel HB, Gheewala B, et al. Diagnostic utility of prostate specific antigen for detection of prostatic lesions. International Journal of Biomedical and Advance Research 2012;03(04):268-72.

10. Djavan B, Zlotta A, Remzi M, et al. Optimal predictors of prostate cancer on repeat prostate biopsy: a prospective study of 1,051 men. J Urol 2000;163(4):1144-9.

11. Bhatt JV, Chitale A, Shah JM, et al. Prostate-assessment to management 2008. URL: www.nhlmmc.edu.in.

12. Akhter R, Reshi R, Dar ZA, et al. Histopathological study of prostatic lesions on needle biopsies with serum prostatespecific antigen (PSA). International Journal of Medicine And Medical Sciences 2014;6(3):87-91.

13. Arora K, Sapre J, Agnihotri AS, et al. Utility of prostate specific antigen in different prostatic lesions, PSA assay. Pathology and Laboratory Medicine 2011;3(1):18-23.

14. Khan IA, Nasir N, Akbar M, et al. Carcinoma of prostate in clinically benign enlarged gland. J Ayub med Coll Abbottabad 2008;20(2):90-2.

15. Sharma P, Patel MM, Raval A, et al. Histopathological lesions in Transrectal ultrasound guided biopsies of prostate in patients with raised serum prostate specific antigen. IJSR 2014;3(11):2277-8179.

16. Mwaakyoma HA, Magandi JL, et al. Correlation of Gleason's score and pretreatment prostate specific antigen in prostate cancer patients. Professional Med J 2010;17(2):235-40.

17. Zivkovic S. Correlation prostate specific antigen and histopathological difference of prostate carcinoma. Arch Oncology 2004;12(3):148-51. 
18. Catalona WJ. Clinical utility of measurements of free and total prostate-specific antigen (PSA): a review. Prostate Supplement 1996;7(Suppl 7):64-9.

19. Yuan JJ, Coplen DE, Petros JA, et al. Effects of rectal examination, prostatic massage, ultrasonography and needle biopsy on serum prostate specific antigen levels. J Urol 1992;147(3 Pt 2):810-4.
20. Weir EG, Partin AW, Epstein JI. Correlation of serum prostate specific antigen and quantitative immunohistochemistry. J Urol 2000;163(6):1739-42. 